\title{
THERMAL EFFECT OF LIGHTING AND WINDOW-TO-WALL RATIO IN MOSQUES: A CASE STUDY IN A HOT CLIMATE - SAUDI ARABIA
}

\author{
MOHAMMED M. ALSHAREEF ${ }^{1}$, MUNEER S. ALOSAIMI ${ }^{1}$, \\ MAMDOOH ALWETAISHI ${ }^{2}$, ASHRAF BALABEL $^{1}$, AHMAD ALAHMADI $^{3}$ \& ALI ALZAED ${ }^{2}$ \\ ${ }^{1}$ Department of Mechanical Engineering, College of Engineering, Taif University, Saudi Arabia \\ ${ }^{2}$ Department of Civil Engineering, College of Engineering, Taif University, Saudi Arabia \\ ${ }^{3}$ Department of Electrical Engineering, College of Engineering, Taif University, Saudi Arabia
}

\begin{abstract}
In mosques, the worshipers must feel comfortable to perform the prayer with reverence and reassurance. The question is whether there is a big difference in temperature ratio in the building upon a slight change of some factors, such as lighting type and window-to-wall ratio, and does the size of windows affect people's thermal comfort in the building or not? This research aims to study the thermal effect resulting from these factors and compare the impact of each of them on the mosque's cooling loads. The King Fahd Mosque in Taif was chosen because it has a free air-conditioning operation with no heating or cooling loads all year round. The size of the windows is large, to study the system accurately. The study has various methods: Simulating the mosque through one of the computer programs (TAS EDSL) and knowing the effect of sunlight concerning the size of the windows and the mosque's lighting on all days of the year. Calculations of the heat effect derived from different lighting types. Also, field monitoring of the mosque using a set of devices to study the building and determine the actual sunlight and lighting effect. Finally, a survey of worshipers about their feeling of thermal comfort in this mosque was also investigated.
\end{abstract}

Keywords: building envelope, hot climate, mosques, Taif city, temperature management, thermal comfort, window-to-wall ratio.

\section{INTRODUCTION}

The mosque represents the most important sacred place for Muslims as it is the place where the greatest worship is performed, which is prayer, reading the Qur'an, performing Friday prayers, and so on. Therefore, It should be a quiet and comfortable place to perform worship in peace, as the number in Saudi Arabia is estimated to be more than 83,995 mosques [1]. These mosques are visited 365 days, five times every day at different times: early morning, afternoon, midday, after sunset, and at night time. Furthermore, mosques represent a unique type of building characterized by an intermittent operating schedule based on prayer times determined by the local solar time [2], and the maximum occupancy time is approximately 30 to 45 minutes for each prayer, according to a study conducted in mosques in Riyadh city [3].

These mosques have unique characteristics from other buildings concerning their shape. They are usually rectangular in shape, simple in design, surrounded by a wall covered with a high ceiling, and the longest part of the building is usually facing the qibla [4]. Also, the nature of praying in the mosque differs from other activities in different buildings. The variation in the number of worshipers from day to day means that the occupancy's intensity is not equal [5]. One of the most critical factors affecting making this mosque a suitable place for worship is cooling and air conditioning, and the thermal loads must be studied for cooling in the winter and heating in the summer to choose the appropriate air conditioning units and meet the requirements of thermal comfort and obtain the best air distribution in the mosque [6]. 
However, air conditioners consume a considerable amount of energy [7], The percentage of energy consumption of buildings from the total energy consumption around the world is a large proportion, estimated at $40 \%$, and this leads to an increase in carbon dioxide emissions in the atmosphere by $30 \%$ of total carbon dioxide [8]. The effects of increased carbon dioxide emissions on various aspects of life are known, such as global warming phenomena [9] and many chronic diseases such as respiratory illnesses, brain damage, etc. [10]. Therefore, it is necessary to study heat transfer methods and try to take advantage of them to rationalize energy consumption. The heat emitted from incandescent lamps contributes to heating the mosque during the winter season, but in the summer - or a hot climate in general - increases the energy losses used in air conditioning systems [11]. Window area plays a vital role in the building's energy performance in terms of heating and cooling. Window size expresses the percentage of window area over room area. Of course, lighting is better if the windows are large, but it affects, as mentioned earlier, the energy consumed [12]. In this research, a study will be made for one of the most important mosques in the city of Taif, which is the King Fahd Mosque, in terms of the quality of the cooling and heating system, and a simulation will be made in the TAS program to study two influencing variables: the lighting type and window-to-wall ratio, and the effect of its values on the thermal loads.

\section{METHODOLOGY}

\subsection{King Fahd Mosque: Location and dimensions}

The King Fahd Mosque is located in Taif city $21^{\circ} 16^{\prime} 39.8^{\prime \prime} \mathrm{N} 40^{\circ} 24^{\prime} 16.9^{\prime \prime} \mathrm{E}$ and an altitude of $1453 \mathrm{~m}$ (Fig. 1). It is one of Taif's largest mosques, with an area of approximately $9,600 \mathrm{~m}^{2}$ and extending the prayer hall Longitudinally, with a ratio of 2:3. Among its features, the dome height is twice the height of the mosque ceiling, as well as the absence of open windows, as it depends on the lighting entering from the sizeable, closed glass windows, which are estimated at 12 windows from both sides, in addition to two windows on the side of the mihrab and the main entrance door. The window's height is $7 \mathrm{~m}$ and its width $6 \mathrm{~m}$, and it is divided into six segments with wooden borders. What distinguishes the mosque's design is that its appearance is similar to the old castles and forts in our Arab and Islamic culture.

Google Maps King Fahd Mosque, Taif

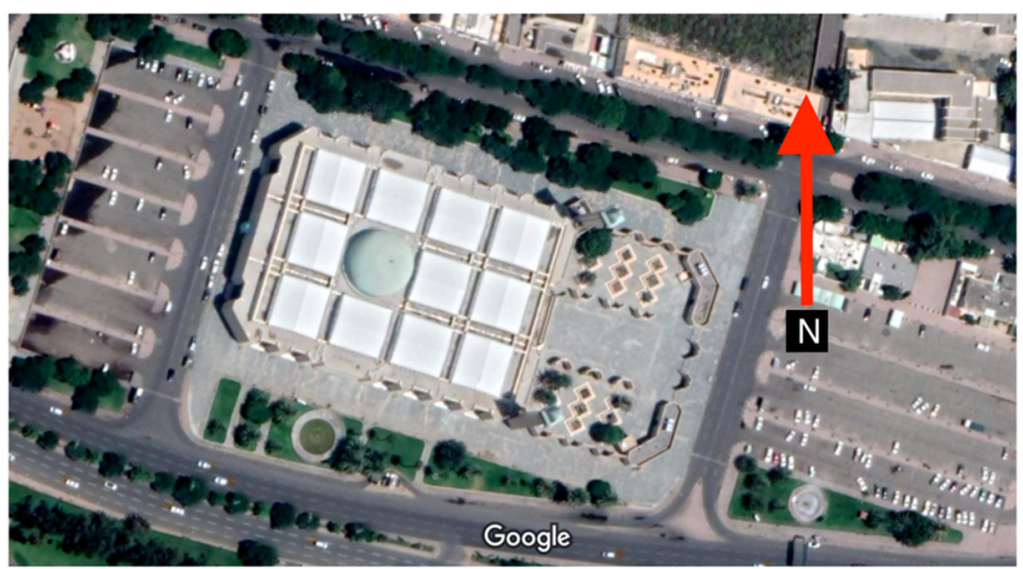

Figure 1: King Fahad Mosque. 


\subsection{Modeling}

The flow chart in Fig. 2 illustrates the different methods used in the methodology of this research, the first of which is modeling. The study used TAS EDSL, one of the most widely used energy software packages, to predict buildings' thermal performance [13]. 3D modeling is done for the mosque to measure how much load are needed to cool the mosque, taking into account changes in the position of the sun during the day as well as changes of seasons of the year and the mosque's location concerning longitude and latitude And some other data on the climate of Taif city.

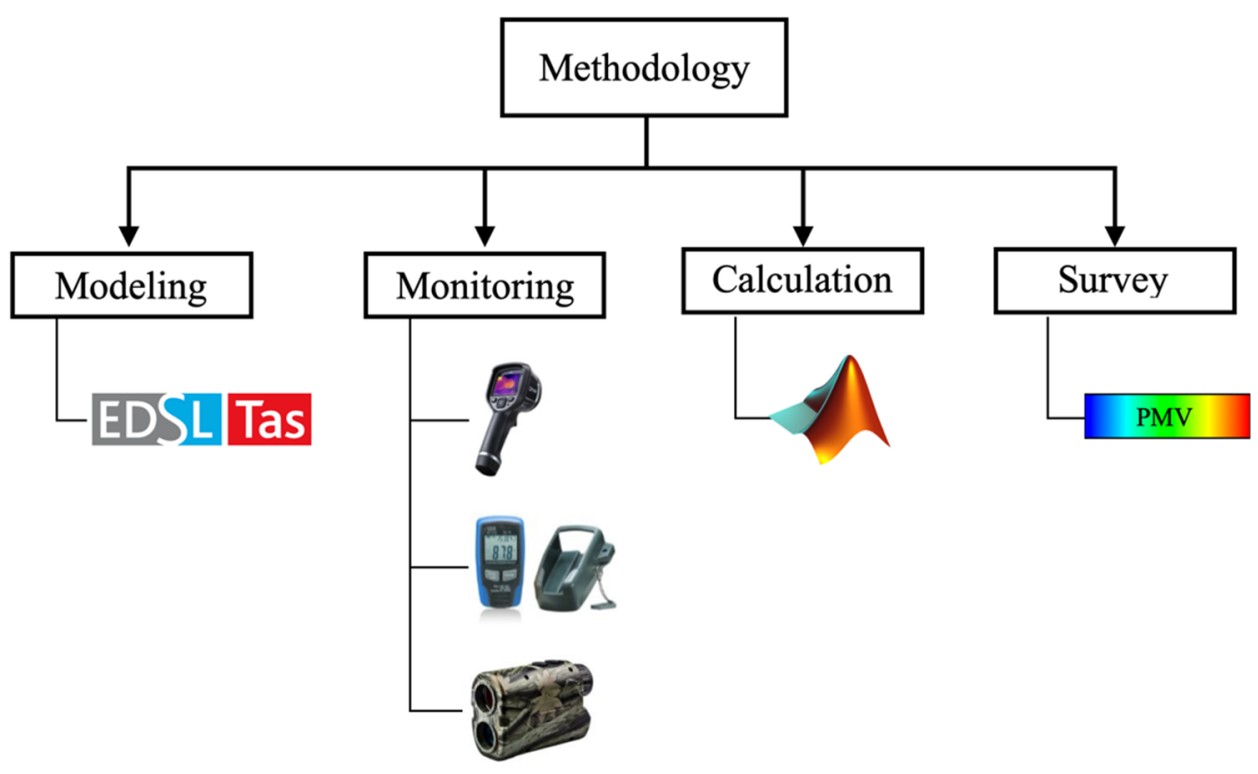

Figure 2: Methodology flowchart.

Some variables were controlled, such as the type of lighting between the incandescent, fluorescent, and light-emitting diode (LED) and its effect on the mosque's temperature throughout the year, in addition to studying the effect of glass and its distribution of heat throughout the mosque by passing sunlight through it. The glazing system is one of the weakest types of building envelope [14]. In this system, all heat transfer processes occur through radiation by sunlight, convection, and conduction. So it was necessary to study this system and model it during all days of the year and know the effect of doors on air movement inside the mosque.

\subsection{Monitoring}

For modeling, the site was visited, and some measurements and monitoring were done. First, the necessary permission to make these measurements was taken from the mosque's imam, and all matters related to the measurements were made easy. Then, some devices were brought to facilitate the study and take the required variables for the research; the devices were as in Table 1. 
Table 1: Tools and equipment used in the study.

\begin{tabular}{ll}
\hline Sensor/tool & Output \\
\hline $\begin{array}{l}\text { Thermal imaging } \\
\text { photos }\end{array}$ & $\begin{array}{l}\text { Temperature range } \\
\text { from }-20 \text { to } 250^{\circ} \mathrm{C} \\
\left(-4 \text { to } 482^{\circ} \mathrm{F}\right)\end{array}$ \\
$\begin{array}{ll}\text { Temperature and } \\
\text { humidity data }\end{array}$ & $\begin{array}{l}\text { - Records } 32,000 \text { data } \\
\text { points } \\
\text { - Built-in sensor to } \\
\text { measure temperature } \\
\text { and humidity }\end{array}$ \\
$\begin{array}{l}\text { Solve simple and } \\
\text { complex mathematical } \\
\text { equations }\end{array}$ \\
$\begin{array}{l}\text { So many energy } \\
\text { elements such as } \\
\text { building } \\
\text { performance tool } \\
\text { cooling load, solar and } \\
\text { daylight } \\
\text { Raser }\end{array}$ & $\begin{array}{l}\text { Measuring distance } \\
\text { Range from } \\
\text { 5m to } 600 \mathrm{~m}\end{array}$ \\
\hline
\end{tabular}

Laser length measuring device for measuring the dimensions of the mosque and measuring windows and doors. A laser distance measuring device was chosen instead of the traditional measuring method to obtain the greatest possible accuracy, especially since this device's error rate is \pm 1 yard $\cong \pm 0.9 \mathrm{~m}$. One of the devices that was used is the thermal camera. The way the device works is that the camera is directed towards the area whose temperature is to be measured. Then the device automatically measures the temperature for everything inside the frame, and the glass's temperature was measured in each of the five prayers. Moreover, the last device used is a data logger, and it was used to measure the temperature and relative humidity in the mosque for 24 hours. Every hour, it measures these variables, and another device was placed in a room inside a house isolated from ventilation and lighting and compared the readings with each other.

\subsection{Calculation}

To make a complete and accurate simulation in the TAS program, that is necessary to calculate the internal heat gain from the lighting system $\left(Q_{H, o}\right)$ and then insert it into the simulator and determine its effect with the rest of the factors. Suszanowicz [15] illustrated 
the method of calculating values by explaining them with three equations; calculations were done using MATLAB software. Thermal power coming out of different types of lighting must be calculated using eqn (1):

$$
P_{h}=m \cdot C_{a} \cdot \Delta \mathrm{T} \cdot t^{-1}
$$

where:

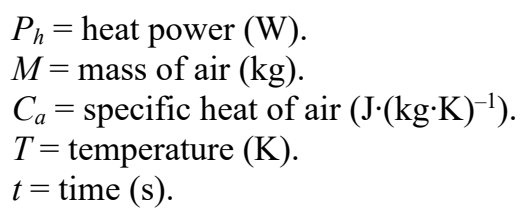

Electrical power in lighting systems is transformed into two types, one of which turns into lighting. The rest turns into heat, and the correlation between electrical power and heat power is expressed as a Heat emission coefficient $\left(H_{e}\right)$. If the result of eqn (2) is equal to 0 , then the source does not emit heat at all, but if the value is equal to 1 , then the source only emits heat. The value of $\left(H_{e}\right)$ is calculated with this formula:

$$
H_{e}=\frac{P_{h}}{P_{e}}
$$

where:

$P_{e}=$ electrical power $(\mathrm{W})$.

A comparison was made between the lighting type used in the mosque, which is compact fluorescent, and LED and incandescent in terms of luminous's value; to find out the equivalent power for each type, as in Table 2.

Table 2: Luminous flux and power for each lighting type.

\begin{tabular}{lcccc}
\hline Type & Luminous flux & $\begin{array}{c}\text { Power } \\
\text { (W) }\end{array}$ & Company \\
\hline LED & $710 \mathrm{~lm}$ & $10 \mathrm{~W}$ & Philips \\
$\begin{array}{l}\text { Compact fluorescent lamps } \\
\text { (CFL) }\end{array}$ & $705 \mathrm{~lm}$ & $12 \mathrm{~W}$ & Philips \\
\hline Incandescent & $710 \mathrm{~lm}$ & $60 \mathrm{~W}$ & Philips \\
\hline
\end{tabular}

After the above variables have been identified and given the datasheet for each type of lighting, the "internal heat gains" that come from lighting $\left(\mathrm{W} / \mathrm{m}^{2}\right)$ can be calculated as in eqn (3):

$$
Q_{L}=E_{v} \cdot \eta^{-1} \cdot H_{e}
$$

where:

$Q_{L}=$ internal heat gain from lighting system per unit area $\left(\mathrm{W} / \mathrm{m}^{2}\right)$. 
$E v=$ illuminance (lx).

$\eta=$ luminous efficacy $(\mathrm{lm} / \mathrm{W})$.

$H_{e}=$ heat emission coefficient $(\mathrm{W} / \mathrm{W})$.

\subsection{Survey}

A survey was conducted for the worshipers in the fall season to measure the extent of the worshipers' feeling of thermal comfort, and the "ASHRAE Standard 55: Thermal Environment Point-In-Time Survey" [16] was adopted in this survey.

\section{RESULTS AND DISCUSSION}

\subsection{Lighting system}

After that calculations to measure the heat produced by the lighting based on the previous equations and comparing the " $H_{e}$ " in the three types of lighting, a significant difference between incandescent which produces heat more than LED with the same luminous flux as shown in Table 3.

Table 3: Comparing QL between different type of light.

\begin{tabular}{lcc}
\hline Type & $\boldsymbol{Q}_{\boldsymbol{L}}\left(\mathbf{W} / \mathbf{m}^{\mathbf{2}}\right)$ & $\begin{array}{c}\text { Luminous efficacy } \\
\boldsymbol{\eta}, \mathbf{I m} / \mathbf{W}\end{array}$ \\
\hline LED & 0.1297 & 71 \\
\hline Compact fluorescent lamps (CFL) & 0.6029 & 58.75 \\
\hline Incandescent & 9.2414 & 11.83 \\
\hline
\end{tabular}

\subsection{Window-to-wall ratio}

There is a direct proportion between the window-to-wall ratio and the amount of heat inside the mosque. Therefore, as in Fig. 3, the lower the window-to-wall ratio, the lower the amount of heat entering the building. Moreover, noon (Dhuhr) is the time when the most heat enters from the windows concerning the times of other prayers, as seen in Fig. 4. It is noteworthy in this mosque that each area of the single window reaches $42 \mathrm{~m}^{2}$. This area's disadvantage is massive, especially when this area's temperature on the south side reaches $44.4^{\circ} \mathrm{C}$ in the Dhuhr prayer as in Fig. 5. While on the north side, as shown in Fig. 6, the temperature is at its highest value of $29.9^{\circ} \mathrm{C}$.

Fig.7 shows the temperatures of the windows at all times of prayer for all directions on the same day.

\subsection{Cooling load}

After knowing the effect of lighting and window-to-wall ratio in this mosque, it is possible to calculate the cooling load needed to achieve the worshipers' appropriate thermal comfort ratio.

During the worshipers' were asked about the amount of thermal comfort they feel, there was a difference in thermal comfort based on the prayer time. For example, no one complains about the temperature during Maghrib prayer time. However, during the Dhuhr prayer, the temperature was high, and the worshipers were less satisfied with the thermal comfort, as shown in Table 4. 


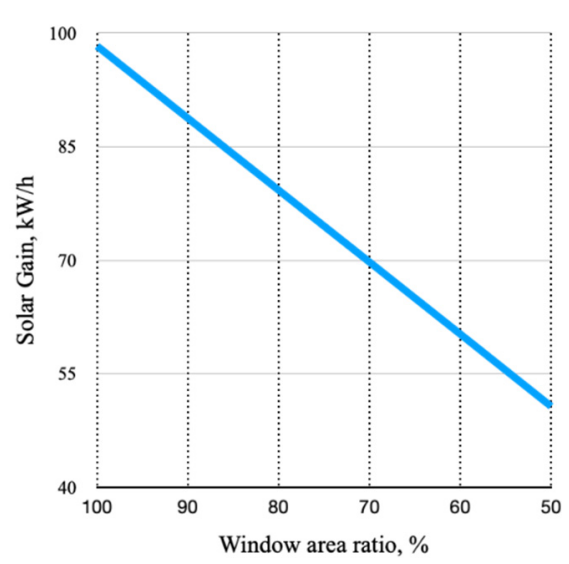

Figure 3: The proportion between window area and solar gain.

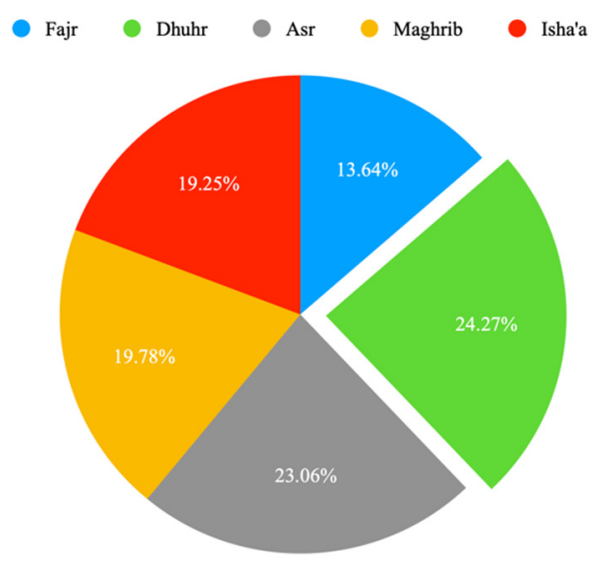

Figure 4: The rate of heat entering the mosque through the windows in each prayer.

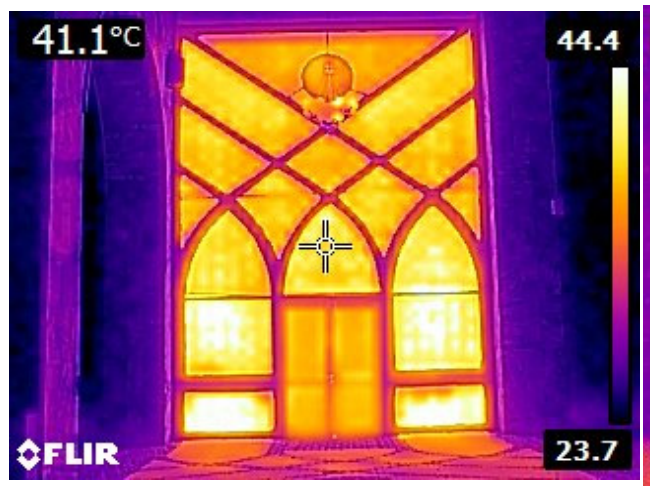

Figure 5: Southern door in Dhuhr prayer.

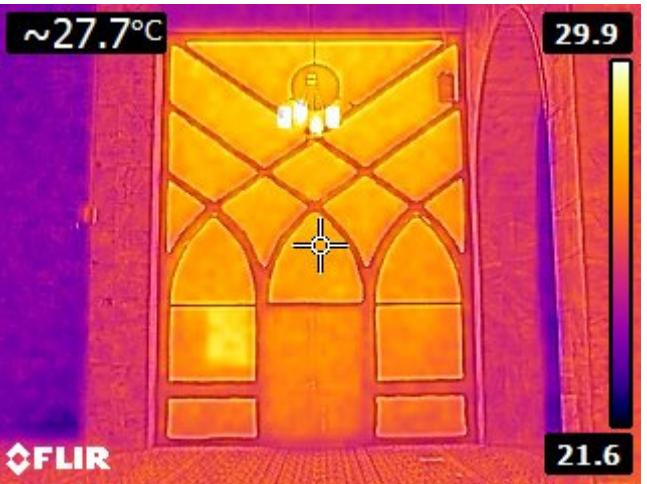

Figure 6: Northern door in Dhuhr prayer.

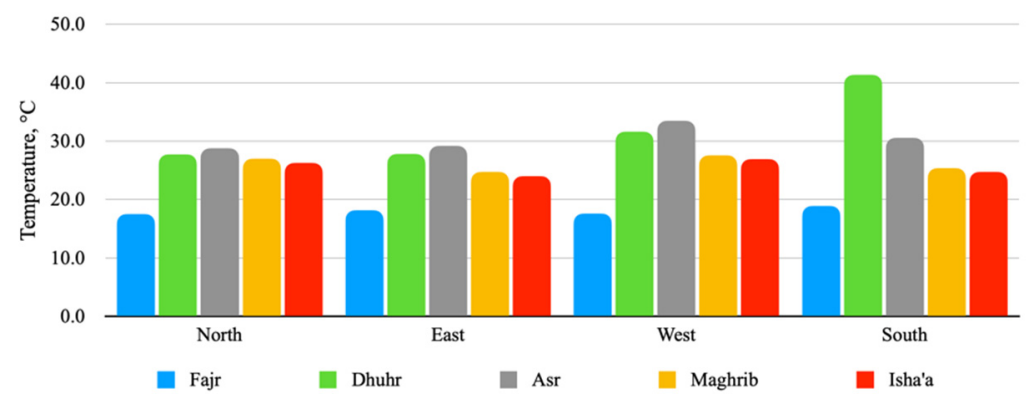

Figure 7: Temperature measurement for windows for all prayers from each direction. 
Table 4: Predicted mean vote (PMV).

\begin{tabular}{|l|c|c|c|c|c|c|c|}
\hline Prayers name & $\begin{array}{c}\text { COLD } \\
-3\end{array}$ & COOL & $\begin{array}{c}\text { SLIGHTLY } \\
\text { COOL }\end{array}$ & $\begin{array}{c}\text { NEUTRAL } \\
0\end{array}$ & $\begin{array}{c}\text { SLIGHTLY } \\
\text { WAM }\end{array}$ & $\begin{array}{c}\text { WARM } \\
+2\end{array}$ & $\begin{array}{c}\text { HOT } \\
+3\end{array}$ \\
\hline Fajr & & & & & & \\
\hline Dhuhr & & & & & & \\
\hline Asr & & & & & & \\
\hline Maghrib & & & & & & \\
\hline Isha'a & & & & & & \\
\hline
\end{tabular}

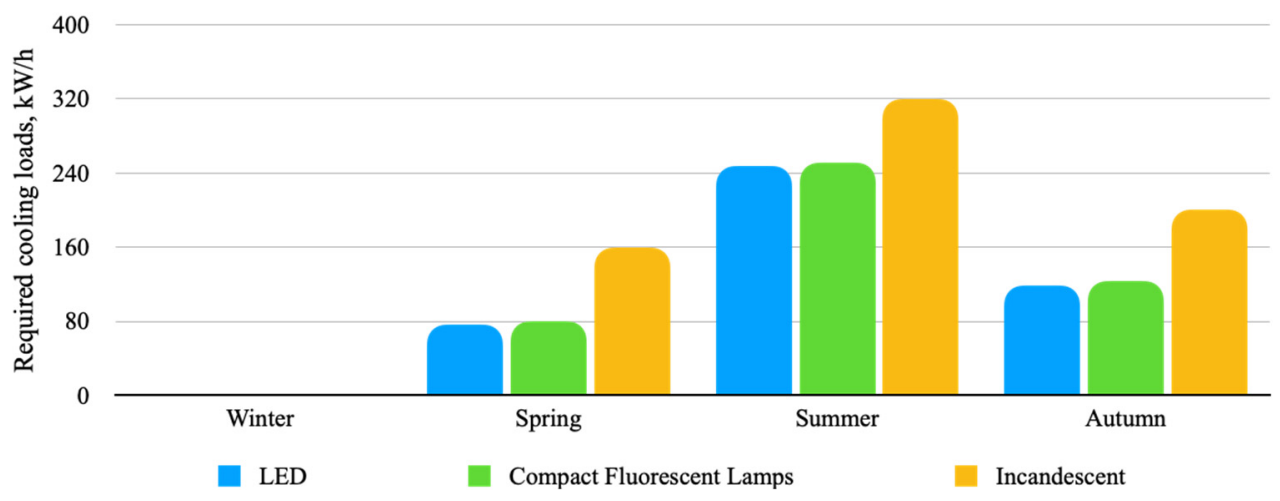

Figure 8: The difference of the required cooling load in the different seasons of the year.

Indeed, the calculation of cooling load differs depending on the external temperature or the seasons of the year in general, and Fig. 8 shows the difference of the required cooling load in the different seasons of the year.

The big difference between changing the type of lighting from LED to Incandescent and reducing window-to-wall ratio into $50 \%$, where the difference approaches $83 \mathrm{~kW} / \mathrm{h}$, as in Table 5.

Table 5: The thermal effect of different types of lighting systems.

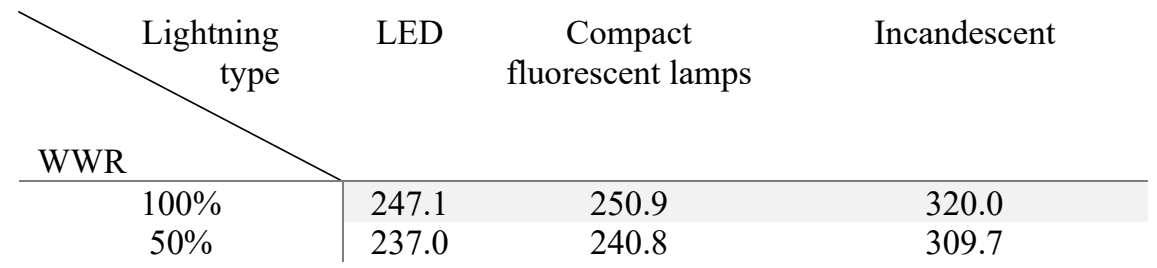

Finally, it is possible to calculate the average thermal participation rate for each windowto-wall ratio and lighting types by Fig. 9 . 


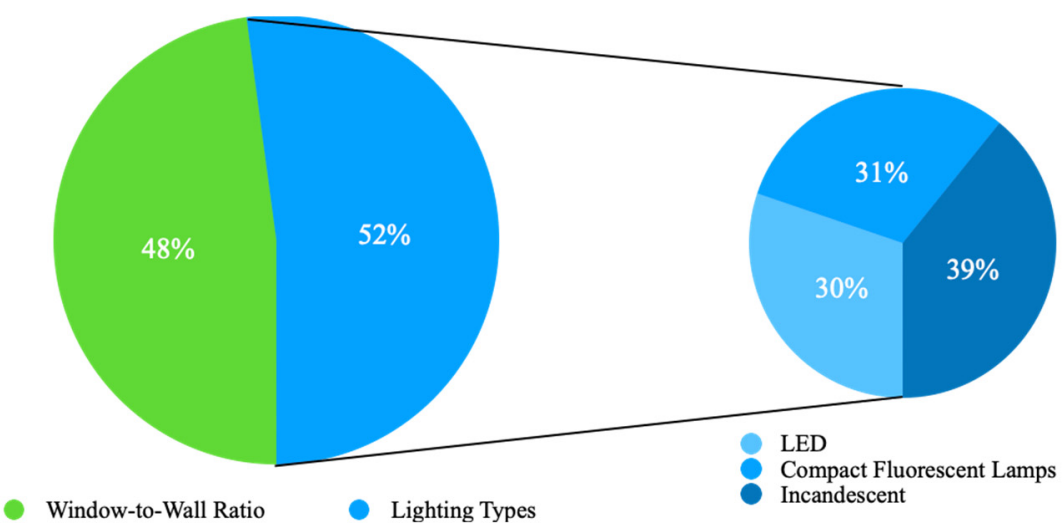

Figure 9: Thermal participation rate for each window-to-wall ratio and lighting types.

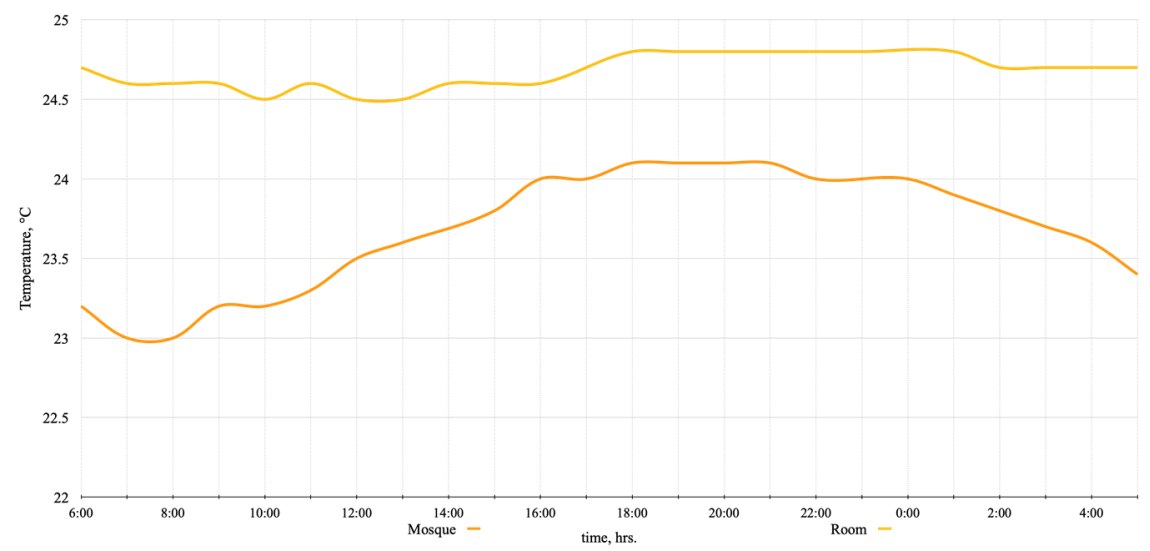

Figure 10: Comparison of temperatures between room and mosque, ${ }^{\circ} \mathrm{C}$.

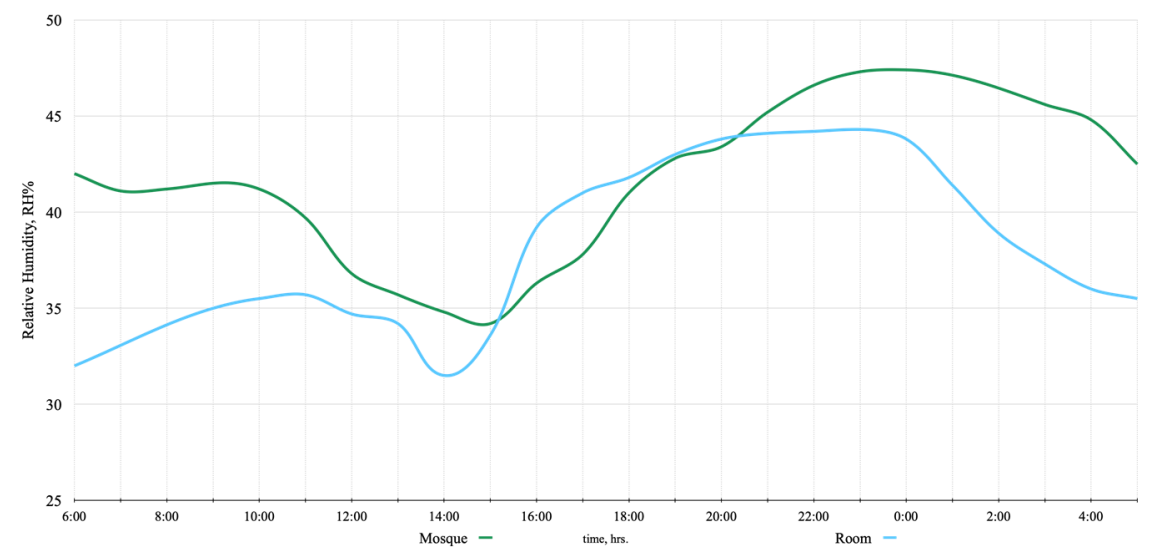

Figure 11: Comparison of relative humidity between room and mosque, RH\%. 
One of the good points in this mosque is that when the temperature and relative humidity were compared between it and a closed room without lights or ventilation (Figs 10 and 11), it was observed that mosque is better in temperature despite a high percentage of window-towall ratio as in Fig. 10. This temperature is due to the thermal mass of the mosque's external wall, which stores the heat inside the wall and contributes to the improvement of the temperature.

\section{REFERENCES}

[1] Ministry of Islamic Affairs Dawah Guidance, Numbers of mosques, employees, charities, preaching centers and offices in the Kingdom and the number of new muslims 1439/1440 A.H., 2018.

[2] Al-Homoud, M.S., Abdou, A.A. \& Budaiwi, I.M., Assessment of monitored energy use and thermal comfort conditions in mosques in hot-humid climates. Energy Build., 41(6), pp. 607-614, 2009. DOI: 10.1016/j.enbuild.2008.12.005.

[3] Al-Shaalan, A.M., Wakeel, A. \& Alohaly, A., Appropriate electric energy conservation measures for big mosques in riyadh city. Appl. Mech. Mater., 492, pp. 24-30, 2014. DOI: 10.4028/www.scientific.net/AMM.492.24.

[4] Budaiwi, I. \& Abdou, A., HVAC system operational strategies for reduced energy consumption in buildings with intermittent occupancy: The case of mosques. Energy Convers. Manag., 73, pp. 37-50, 2013. DOI: 10.1016/j.enconman.2013.04.008.

[5] Kassim, N., Abdullah, N. \& Taib, Z.B.M., Decoration in praying hall of mosque: A review of current literature. Procedia -Soc. Behav. Sci., 153, pp. 55-60, 2014.

DOI: $10.1016 /$ j.sbspro.2014.10.040.

[6] Hashim, H.M., Sokolova, E., Derevianko, O. \& Solovev, D.B., Cooling load calculations. IOP Conf. Ser. Mater. Sci. Eng., 463(3), 2018.

DOI: 10.1088/1757-899X/463/3/032030.

[7] Saudi Electricity Company, Optimal use of air conditioner, 2015.

[8] Yang, Q., Liu, M., Shu, C., Mmereki, D., Uzzal Hossain, M. \& Zhan, X., Impact analysis of window-wall ratio on heating and cooling energy consumption of residential buildings in hot summer and cold winter zone in China. J. Eng. (United Kingdom), 2015, 2015. DOI: 10.1155/2015/538254.

[9] Ali, M., Athar, M. \& Ali, E., The emissions and environmental impact of power plants operating on fossil fuel at Distt. Kasur, Pakistan. Ekoloji, 16(63), pp. 74-80, 2007.

[10] Dong, Y., Wang, X., Jin, J., Qiao, Y. \& Shi, L., Air pollution, pollutant emissions and harmfull effects. J. Eng. Technol. Manag., 34(2), pp. 78-98, 2014.

[11] Pumar, M., Efficient of the bulbs, May, pp. 1-83, 2010.

[12] Eljojo, A., Effect of windows size, position and orientation on the amount of energy needed for winter heating and summer cooling. J. Eng. Res. Technol., 1(1), pp. 1-8, 2017. DOI: 10.13140/RG.2.2.32424.47361.

[13] Alwetaishi, M., Human thermal comfort and building performance of schools in hot and humid climate with a particular reference to Saudi Arabia, Jeddah, 2015.

[14] Alwetaishi, M., Impact of glazing to wall ratio in various climatic regions: A case study. J. King Saud Univ. - Eng. Sci., 31(1), pp. 6-18, 2019.

DOI: 10.1016/j.jksues.2017.03.001.

[15] Suszanowicz, D., Internal heat gain from different light sources in the building lighting systems. E3S Web Conf., 19, 2017. DOI: 10.1051/e3sconf/20171901024.

[16] ASHRAE, ASHRAE/ANSI Standard 55-2010: Thermal environmental conditions for human occupancy. Int. J. Refrig., 2(1), pp. 56-57, 2010.

DOI: 10.1016/0140-7007(79)90114-2. 